\title{
Effectiveness of Ethanol Extract Mangosteen Peel (Garcinia Mangostana L.) in Accelerating Post-Tooth Extraction Healing in Wistar Rats
}

\author{
Dong Qian ${ }^{\mathbf{1}}$, Florenly ${ }^{\mathbf{2}}$ Liena $^{\mathbf{3}}$, Dewi Riastawaty Purba ${ }^{\mathbf{4}}$ \\ ${ }^{1,2,3,4}$ Departement of Medicine, Faculty of Medicine, Universitas Prima Indonesia \\ ly@unprimdn.ac.id
}

\begin{abstract}
Tooth extraction will cause a wound in the form of alveolar bone that opens in the oral cavity. Mangosteen peel has various pharmacological effects such as anti-inflammatory, antioxidant, antidiabetic, and antibacterial. The goal of this study was to find out the effectiveness of Mangosteen Peel Ethanol Extract (Garcinia mangostana L.) 45\% with 90\% in speeding up the healing time of post-tooth extraction wounds in Wistar rats. This type of research is an experimental laboratory with a post-test pattern only control group design. Conducted at the Laboratory of Pharmacology \& Laboratory of Traditional Medicine Faculty of Pharmacy, University of North Sumatra January-March 2021. The animal is a male Wistar rat of 32 who is physically healthy. The size of the sample is determined by Federer's formula, the minimum sample size for each treatment is 16 rats. The results of the study that there is a significant relationship between the amount of fibroblast tissue per field of view in Wistar Rats after tooth extraction with the administration of mangosteen peel (Garcinia mangostana L.) with a concentration of $45 \%$ and mangosteen peel (Garcinia mangostana L.) concentration 90\%, $p=0.036$ ( $p<0.05$ ). Mangosteen skin extract (Garcinia mangostana L.) is $45 \%$ and $90 \%$ effective in speeding up wound healing time after extraction of rat teeth Wistar. Mangosteen skin extract (Garcinia mangostana L.) is $90 \%$ more effective than turmeric extract (Curcuma longa) $45 \%$ in speeding up wound healing time postextraction of rat teeth Wistar due to the flavonoid content in mangosteen skin extract (Garcinia mangostana L.) 90\% which helps accelerate wound healing higher than skin extract Mangosteen (Garcinia mangostana L.) $45 \%$.
\end{abstract}

Keywords: mangosteen; extraction; teeth

\section{Introduction}

Riskesdas results in 2013 showed the DMFT index of Indonesian people nationally at 4.6 with the largest component being missing teeth of 2.9 (Riskesdas 2013). Tooth extraction will cause a wound in the form of alveolar bone that opens in the oral cavity. Injury is anatomical damage or partial damage to tissue due to trauma. The severity of the injury depends on the magnitude of the trauma received by the tissue. Physiologically, the body can repair damage to skin tissue (wounds) itself known as wound healing (Sorongan and Siagian 2015). Research at RSGM PSPDG FK UNSRAT describes the prevalence of tooth extraction complications, namely bleeding by $4.54 \%$ and swelling by $2.27 \%$ (Lande, Kepel, and Siagian 2015).

Normal wound healing is a complex and dynamic process. The wound healing process can be divided into three main phases namely, the inflammatory phase, the proliferation phase and the remodeling phase (Suryadi 2013). The main cells involved in the wound healing process are fibroblasts (Marchianti, Nurus Sakinah, and Diniyah 2017). Fibroblasts are stem cells that play a role in forming and putting fibers in the matrix, especially collagen fibers (dr. Gede Wirata 2018). Herbal products have been used since long ago in the medical world, side effects are also not like chemical durgs (Putri 2020); (Fitriyah et al. 2013) 
So there has been a lot of research done to explore the various benefits of natural ingredients, one of which is mangosteen peel. Mangosteen peel methanol extract (Garcinia mangostana L.) contains saponin compounds, alkaloids, flavonoids, triterpenoids, tannins and polifenol (Putri, Warditiani, and Larasanty 2013); (Puspitaningrum, Kusmita, and Setyani 2014); (Wehantouw and Manurung 2011). Mangosteen peel has various pharmacological effects such as: anti-inflammatory, antioxidant, antidiabetic, and antibacterial (Yanti 2021); (Chin 2011); (Kemala, Hendiani, and Satari 2018).

In general, mangosteen peel is a shell that is discarded by consumers or can be called agricultural waste. So far the use of mangosteen skin is only for tanning skin, traditional medicine and materials that make antiques and textile dyes. Utilization of mangosteen peel for treatment in Indonesia is still not much. Therefore, the author is interested in researching about the Effectiveness of Mangosteen Peel Ethanol Extract (Garcinia mangostana L.) $45 \%$ with $90 \%$ in speeding up the healing time of post-tooth extraction wounds in wistar rats. The goal of this study was to find out the effectiveness of mangosteen peel ethanol extract (Garcinia mangostana L.) $45 \%$ with $90 \%$ in speeding up the healing time of post-tooth extraction wounds in wistar rats.

\section{Review of Literature}

Tooth extraction is the act of removing or removing teeth from the alveolus. Tooth extraction is also a surgical action involving hard tissue and soft tissue from the oral cavity (Lande et al. 2015). Complications due to tooth extraction can occur due to various factors and vary in terms of what they cause. Complications that are often encountered in tooth extraction include bleeding, swelling, pain, dry socket, fractures (HM 2014). The main phytochemical present in mangosteen peel is xanthone terisoprenlation (Putra SR 2012), class of secondary metabolites with many reports of biological effects, such as antioxidants, proapoptosis, anti-proliferative, antinosiseptif, anti-inflammatory (Parmita, In, and Armyanti 2017), neuroprotective, hypoglycemic, and anti-obesity (Ovalle-Magallanes, Eugenio-Pérez, and Pedraza-Chaverri 2017).

According to research conducted by Pasaribu, et al. (2012), ethanol extract 96\% mangosteen peel contains chemical compounds alkaloida, flavonoids, glycosides, saponins, tannins and steroids/ triterpenoids (Bahri, Pasaribu, and Sitorus 2012). Antipyretic analgesics are compounds that can relieve pain and can lower fever. The content of flavonoids and alkaloids mangosteen skin can have an effect as an analgesic. In addition, flavonoids are able to inhibit prostaglandins so that they have antipyretic effects (Puspitaningrum et al. 2014).

\section{Research Methods}

This type of research is an experimental laboratorik that uses randomly controlled design with post-test only control group design patterns. Conducted at the Laboratory of Pharmacology \& Laboratory of Traditional Medicine Faculty of Pharmacy, University of North Sumatra and Anatomical Pathology Laboratory of the Faculty of Medicine, University of North Sumatra, which was conducted from January-March 2021. The animal is a male Wistar rat as many as 32 who are physically healthy, aged 2-3 months with a weight between 200-250 grams. Rats will be divided into two groups, namely, 16 rats were treated with mangosteen skin extract (Garcinia mangostana L.) 45\% and 16 rats were given mangosteen skin extract (Garcinia mangostana L.) $90 \%$ to see the comparison of accelerated wound 
healing after tooth extraction. The size of the sample is determined by Federer's formula, namely: $(\mathrm{t}-1)(\mathrm{r}-1) \geq 15$. So, the minimum sample for each treatment is 16 rats.

\subsection{Tool}

1. The animal cage is assigned a numbered code.

2. Diagnostic set (glass mouth, sonde, tweezers).

3. Nierbeken.

4. Tang tooth extraction (needle holder used) in sterile conditions.

5. Spray.

6. Gloves.

7. Mask.

8. Jaw-ready petri dish.

9. Set of histological preparation manufacturing tools.

10. Microscope.

\subsection{Material}

Materials used in research:

1. Mangosteen peel extract (Garcinia mangostana L.) $45 \%$

2. Mangosteen peel extract (Garcinia mangostana L.) $90 \%$

3. Ketamine.

4. Formalin $10 \%$.

5. Histological preparation materials with Hematoxylin Eosin staining.

6. Alcohol $70 \%$ as a sterilization material.

7. Cotton pellet

\subsection{Treatment of Wistar Rats}

Before the treatment, the test animals (rats) numbering 32 were divided into 2 groups, namely the mangosteen skin extract treatment group (Garcinia mangostana L.) $45 \%$ and mangosteen peel extract (Garcinia mangostana L.) 90\%. After that, all the mice were adapted for one week. Animals were put in cages, with a total of 5 rats in each cage under the same environmental conditions and fed the same food, and monitored for health. Removal of mouse teeth will be done using modifications of the needle holder under the anaesthetic effect of ketamine $1000 \mathrm{mg} / 10 \mathrm{ml}$ dose of $20 \mathrm{mg} / \mathrm{kg}$ bb intraperitonial. Every day the extraction of incisive teeth 1 in every 5 rats. After tooth extraction, re-observe the extraction scar and give a tampon (cotton pellet) to stop bleeding in the wound for 5 minutes. Tested mangosteen skin extract (Garcinia mangostana L.) $45 \%$ in treatment group I, drop mangosteen peel extract (Garcinia mangostana L.) $90 \%$ in treatment group II shortly after tooth extraction as much as $0.05 \mathrm{ml}$ daily. After revocation and treatment, test animals (rats) are fed fine porridge with attention to the health of test animals. On the 5th day after tooth extraction, mice from each group were sacrificed by physical means i.e. by neck dislocation. The tail of the mouse is held and then placed on a surface that can be reached. The mouse will stretch its body, when the rat's body stretches, at the nape of the neck is placed a restraint held with the left hand. The tail is pulled with the right hand hard, so that the neck of the mouse will be dislocated. Then the mouse jaws were taken.

Then the tissue is fixated with $10 \%$ formalin for 24 hours at room temperature, then the decalcification process is carried out using a solution of Ethylene Diamine Tetra Acetic Acid (EDTA 10\%) at room temperature. Then the process of dehydrating the tissues using alcohol. The specimen is put into a solution of toluol alcohol (1:1), using pure toluol, then put into a solution of saturated paraffin toluol. The next process is infiltration in the oven by way of the 
specimen inserted into liquid paraffin. The embedding process (inserting the network into paraffin) and after that is labeled / code. After the embedding stage is complete, the tissue is sliced in series with a thickness of approximately 6 microns using microtoms. The process of evaluating fibroblast cell response uses hematoxylin eosin (HE) coloring. The procedure that must be done is deparafination using a solution of xylol and alcohol, then continued with the rehydration process with alcohol. After that it is washed with running water, then rinsed with aquadest and then wiped. The glass object is then put in Meyer's hematoxolin solution and washed with running water, then rinsed with aquadest, after which the staining is assessed under a light microscope. If the staining has been considered good, then proceed to the next step, namely the process of dehydration with alcohol in a stratified manner then wiped. The next stage, inserted into the solution xylol and object glass closed with deck glass and made observations using a light microscope. The density of fibroblasts is assessed by counting the number of fibroblasts at 5 points of view.

\subsection{Histopathological Scoring Parameters for Fibroblast Counts}

Histopathological scoring parameters for knowing the distribution of fibroblast tissues are carried out based on field of view are (Nanda, Salim, and Iskandar 2017):

Table 1. Parameters of Histopathological Scoring

\begin{tabular}{lll}
\hline 1 & $(-)$ & No fibroblast tissue was found. \\
\hline 2 & $(+)$ & slight number of fibroblasts (less than 10\% per field of view) \\
\hline 3 & $(++)$ & moderate fibroblast tissue (10\%-50\% per field of view) \\
\hline 4 & $(+++)$ & large number of fibroblast tissue (50\%-100\% per field of view) \\
\hline
\end{tabular}

\subsection{Data Analysis}

The data analysis used in the study used the nonparametric Chi-Square Test, with a significant level of 0.05 .

\section{Discussion}

\subsection{Results}

a. Distribution Data and Frequency of Fibroblast Tissues per Field of View PostExtraction

Distribution of data and frequency of the amount of fibroblast tissue per field of view in Wistar Rats after tooth extraction group given mangosteen peel extract (Garcinia mangostana L.) $45 \%$ and $90 \%$ can be seen as follows:

Table 2. Distribution and Frequency Data on The Number of Fibroblasts Per Field of View Post-Tooth Extraction

\begin{tabular}{llcccc}
\hline \multirow{2}{*}{ NO } & \multirow{2}{*}{ Number of Fibroblasts } & \multicolumn{4}{c}{$\begin{array}{c}\text { Mangosteen Peel Extract (Garcinia } \\
\text { mangostana L.) }\end{array}$} \\
\cline { 3 - 6 } & & \multicolumn{3}{c}{$\begin{array}{c}\text { Concentration } \\
\mathbf{4 5 \%}\end{array}$} & \multicolumn{2}{c}{ Concentration 90 \% } \\
\cline { 3 - 6 } & & $\mathbf{n}$ & $\mathbf{\%}$ & $\mathbf{n}$ & \% \\
\hline 1 & No fibroblast tissue was found. & 0 & 0 & 0 & 0 \\
\hline 2 & $\begin{array}{l}\text { Slight number of fibroblasts (less } \\
\text { than 10\% per field of view). }\end{array}$ & 8 & 25.1 & 3 & 5.4 \\
\hline 3 & $\begin{array}{l}\text { Moderate fibroblast tissue (10\%-50\% } \\
\text { per field of view). }\end{array}$ & 5 & 13.2 & 8 & 22.3 \\
\hline
\end{tabular}




\begin{tabular}{llllll}
\hline 4 & $\begin{array}{l}\text { The amount of fibroblastic tissue is } \\
\text { large (50\%-100\% per field of view) }\end{array}$ & 4 & 9.34 & 8 & 23.2 \\
\hline
\end{tabular}

From the table 2. Can be seen all samples found fibroblast tissue in the administration of mangosteen peel (Garcinia mangostana L.) $45 \%$ and $90 \%$ after the extraction of teeth Wistar rats. The number of fibroblasts found in the category is slight (less than $10 \%$ per field of view) in the administration of mangosteen peel extract (Garcinia mangostana L.) $45 \%$ after tooth extraction wistar rats as much as $8(25.1 \%)$ tails and in the administration of mangosteen peel extract (Garcinia mangostana L.) $90 \%$ as much as $3(5.4 \%)$ tails. The number of fibroblasts found in the moderate category $(10 \%-50 \%$ per field of view) in the administration of mangosteen peel (Garcinia mangostana L.) $45 \%$ after tooth extraction of Wistar Rats as much as $5(13.2 \%)$ tails and in the administration of mangosteen peel extract (Garcinia mangostana L.) $90 \%$ of $8(22.3 \%)$ tails. The number of fibroblasts found in many categories $(50 \%-100 \%$ per field of view) in the administration of mangosteen peel (Garcinia mangostana L.) $45 \%$ after tooth extraction of Wistar rats as much as $4(9.34 \%)$ tails and in the administration of mangosteen peel (Garcinia mangostana L.) $90 \%$ as much as $8(23.2 \%)$ tails.

\section{b. Association of Fibroblast Tissue per Field of View in Wistar Rats Post Tooth Extraction with Administration of Mangosteen Peel Extract (Garcinia mangostana L.) Concentrations of $45 \%$ and $90 \%$}

To find out the relationship of the amount of fibroblast tissue per field of view in Wistar Rats after tooth extraction with the administration of mangosteen peel (Garcinia mangostana L.) with a concentration of $45 \%$ and mangosteen peel (Garcinia mangostana L.) $90 \%$ concentration, data analysis is carried out using the Chi Square test as follows:

Table 3. Association of Fibroblast Tissue Per Field of View in Wistar Rats Post Tooth Extraction with Administration of Mangosteen Peel Extract (Garcinia mangostana L.)

Concentrations of $45 \%$ and $90 \%$

\begin{tabular}{|c|c|c|c|}
\hline \multirow{2}{*}{ Number of Fibroblasts } & \multicolumn{3}{|c|}{$\begin{array}{c}\text { Mangosteen peel extract (Garcinia mangostana } \\
\text { L.) }\end{array}$} \\
\hline & $\begin{array}{c}\text { Concentration } \\
45 \%\end{array}$ & $\begin{array}{c}\text { Concentration } 90 \\
\%\end{array}$ & $\begin{array}{c}\text { p- } \\
\text { value }\end{array}$ \\
\hline No fibroblast tissue was found. & 0 & 0 & \multirow{4}{*}{$0,036^{*}$} \\
\hline $\begin{array}{l}\text { Slight number of fibroblasts (less than } \\
10 \% \text { per field of view) }\end{array}$ & 8 & 3 & \\
\hline $\begin{array}{l}\text { Moderate fibroblast tissue }(10 \%-50 \% \\
\text { per field of view) }\end{array}$ & 5 & 8 & \\
\hline $\begin{array}{l}\text { Large number of fibroblast tissue (50\% } \\
100 \% \text { per field of view). }\end{array}$ & 4 & 2 & \\
\hline
\end{tabular}

Significant $\mathrm{p}<0.05$. Test Chi Square

From the table 3. It can be seen that there is a significant relationship between the amount of fibroblast tissue per field of view in Wistar Rats after tooth extraction with the administration of mangosteen peel (Garcinia mangostana L.) with a concentration of $45 \%$ and mangosteen peel (Garcinia mangostana L.) concentration of 90\%, $p=0.036(p<0.05)$.

\subsection{Discussion}

Tooth extraction is the process of removing teeth both intact and the rest of the roots of the alveolar because it can no longer be treated (Lande et al. 2015). Tooth extraction will cause a wound in the form of alveolar bone that opens in the oral cavity. A wound is 
anatomical damage or partial damage to tissue due to trauma. The body will repair tissue damage (wounds) known as the wound healing process and starts from the occurrence of the wound until the closure of the wound (Sugiaman 2011). The main cells involved in the wound healing process are fibroblasts. The proliferation of fibroblasts determines the final outcome of wound healing. This is because fibroblasts will produce collagen that will link the wound and affect the recapitalization process that will close the wound (Sumbayak 2015).

From the results of this study obtained that all samples found fibroblast tissue in the administration of mangosteen skin extract (Garcinia mangostana L.) $45 \%$ and $90 \%$ postextraction of rat teeth wistar. The number of fibroblasts found in the category is small (less than $10 \%$ per field of view) in the administration of mangosteen skin extract (Garcinia mangostana L.) $45 \%$ post-extraction of rat teeth wistar as much as $8(25.1 \%)$ tails and in the administration of mangosteen skin extract (Garcinia mangostana L.) $90 \%$ as much as 3 (5.4\%) tails. The number of fibroblasts found in the moderate category (10\%-50\% per field of view) in the administration of mangosteen peel (Garcinia mangostana L.) $45 \%$ after tooth extraction of Wistar Rats as much as $5(13.2 \%)$ tails and in the administration of mangosteen peel extract (Garcinia mangostana L.) $90 \%$ of $8(22.3 \%)$ tails. The number of fibroblasts found in many categories (50\%-100\% per field of view) in the administration of mangosteen peel (Garcinia mangostana L.) $45 \%$ after tooth extraction of Wistar rats as much as $4(9.34 \%)$ tails and in the administration of mangosteen peel (Garcinia mangostana L.) $90 \%$ as much as $8(23.2 \%)$ tails.

Based on the analysis of Chi Square data, there was a significant association between the amount of fibroblast tissue per field of view in wistar rats after tooth extraction with the administration of mangosteen peel extract (Garcinia mangostana L.) 45\% and mangosteen peel extract (Garcinia mangostana L.) 90\%, $\mathrm{p}=0.036(\mathrm{p}<0.05)$. This is clearly seen in the distribution of data on the number of fibroblasts that are large (50\%-100\% per field of view) in mangosteen peel extract (Garcinia mangostana L.) $90 \%$ as much as 2 samples and in mangosteen skin extract (Garcinia mangostana L.) 45\% 4 samples.

A small amount of fibroblasts (less than $10 \%$ per field of view) was also found more in mangosteen peel extract (Garcinia mangostana L.) $45 \%$ which is as many as 8 samples while in mangosteen peel extract (Garcinia mangostana L.) $90 \%$ only found as many as 3 samples. The results of this study are supported by Yulia's 2013 research, on the influence of mangosteen peel extract (Garcinia mangostana L.) against the number of fibroblasts in the gingiva of male wistar rats after the induction of Porphyromonas gingivalis. The results of this study showed mangosteen peel extract (Garcinia mangostana L.) had an influence on the closing time of the sores on the mucosa of the oral cavity of wistar rats. Wounds in wistar rats given mangosteen skin extract (Garcinia mangostana L.) are more quickly covered than wistar rats that are not given mangosteen peel extract (Yulia 2013).

Active substances such as manosa, glucomannan, chrysanthemum acid, acemannan, flavonoids, saponins, tannins, vitamin A, vitamin $\mathrm{C}$, vitamin $\mathrm{E}$ and enzymes contained in mangosteen peel extract (Garcinia mangostana L.) are very helpful in the wound healing process (Khairani et al. 2020). Research on antioxidant activity mentions that mangosteen skin can speed up the process of cell recovery by speeding up the fibroblast proliferation process (Maulina and Sugihartini 2015). In addition, the presence of anti-inflammatory effects of xanton triggers the formation of collagen which plays an important role in the maintenance of structure and wound healing (Aryati et al. 2018).

According to (Nugroho 2020), The main compound contained in the skin of mangosteen fruit is xanton, which turns out to be responsible for some of the pharmacological activities of mangosteen peel. In xanton compounds there is an important component for wound healing, namely gammamangostin. The content of gammamangostin in the skin of mangosteen fruit plays a 
role in triggering the formation of collagen which plays an important role in the maintenance of wound structure and healing. In addition, there are also other compounds in mangosteen skin that have anti-inflammatory activities, such as flavonoids, vitamin B1, B2, C, saponins, and tannins that can also accelerate wound healing (Kusmita et al. 2014). From the results of this study it can be seen that mangosteen peel extract (Garcinia mangostana L.) is $90 \%$ more effective in the wound healing process than mangosteen skin extract (Garcinia mangostana L.) $45 \%$ because the higher the concentration of extract, the higher the content of mangosteen skin extract (Garcinia mangostana L.) is also higher, so the wound healing process is faster.

\section{Conclusion}

Mangosteen skin extract (Garcinia mangostana L.) $45 \%$ and $90 \%$ effective in speeding up wound healing time after extraction of rat teeth Wistar.Mangosteen skin extract (Garcinia mangostana L.) $90 \%$ more effective than turmeric extract (curcuma longa) $45 \%$ in speeding up wound healing time post-extraction of rat teeth wistar due to the flavonoid content in mangosteen skin extract (Garcinia mangostana L.) 90\% which helps accelerate wound healing higher than mangosteen skin extract (Garcinia mangostana L.) $45 \%$.

\section{References}

Aryati, Yosephine Vania Prima, Iwan Setiawan, Nofi Risa Ariani, and Diah Dwi Hastuti. 2018. "Pengaruh Gel Kombinasi Ekstrak Kulit Semangka ( Citrullus Lanatus( Thunb.)) Dan Ekstrak Kulit Manggis (Garcinia Mangostana L.) Terhadap Penyembuhan Luka Bakar Pada Kelinci.” JPSCR : Journal of Pharmaceutical Science and Clinical Research 3(2): 117.

Bahri, S., F. Pasaribu, and P. Sitorus. 2012. "Uji Ekstrak Etanol Kulit Buah Manggis (Garcinia Mangostana ,L) Terhadap Penurunan Kadar Glukosa Darah.” Journal of Pharmaceutics and Pharmacology 1(1):1-8.

Chin, Young-Won. 2011. "A Popular Botanical Dietary Supplement." Mini Rev Org Chem $5(4): 355-64$.

Dr. Gede Wirata, S. Ke. 2018. "Perubahan Fibroblas Pada Penuaan.” 6(1):102-6.

Fitriyah, Nikmatul, Mahendrata K. Purwa, M. Afif Alfiyanto, Nila Wahuningsih, and Joko Kismanto. 2013. "Obat Herbal Antibakteri Ala Tanaman Binahong." Jurnal KesMaDaSka 116-22.

HM, Chandra. 2014. Buku Petunjuk Praktis Pencabutan Gigi (1st Ed). Makassar: Sagung Seto.

Kemala, Dwita, Ina Hendiani, and Mieke Hemiawati Satari. 2018. "Uji Daya Antibakteri Ekstrak Etanol Kulit Buah Manggis (Garcinia Mangostana L) Terhadap Streptococcus Sanguinis ATCC 10556." Padjadjaran Journal of Dental Researchers and Students 2(2): 137.

Khairani, Tetty Noverita, Ruth Mayana Rumanti, Afri Manao, Dosen Farmasi, Fakultas Farmasi, Institut Kesehatan Helvetia, Mahasiswa Farmasi, Fakultas Farmasi, Institut Kesehatan Helvetia, Tetty Noverita, Khairani Institut, Kesehatan Helvetia, Jl Kapten, and Sumarsono No. 2020. "Formulasi Sediaan Krim Ekstrak Etanol Kulit Buah Manggis ( Garcinia Mangostana L .) sebagai Obat Luka Bakar pada Tikus Putih Jantan Cream Formulation of Ethanol Extract Of Mangosteen Peel ( Garcinia Mangostana L .) As A Burn Healing In White Male Rats Ala." 4(2):53-58.

Kusmita, Lia, Ika Puspitaningrum, Fakultas Famasi, Sekolah Tinggi Ilmu Farmasi, and Yayasan Pharmasi. 2014. "Uji Aktivitas Gel Ekstrak Etanol Kulit Buah Manggis 
(Garcinia Mangostana L.) sebagai Penyembuh Luka Bakar pada Kulit Punggung Kelinci Activity of Gel Mangosteen Rind Aethanol Extract (Garcinia Mangostana L.) Toward Burns Healing On Skin Rabbit." Media Farmasi Indonesia 9(1):606-15.

Lande, Randy, Billy J. Kepel, and Krista V. Siagian. 2015. "Gambaran Faktor Risiko Dan

Komplikasi Pencabutan Gigi Di Rsgm Pspdg-Fk Unsrat.” E-GIGI 3(2).

Marchianti, Ancah., Elly. Nurus Sakinah, and Nunad. et al. Diniyah. 2017. "Digital Repository Universitas Jember Digital Repository Universitas Jember." Efektifitas Penyuluhan Gizi Pada Kelompok 1000 HPK Dalam Meningkatkan Pengetahuan Dan Sikap Kesadaran Gizi 3(3):69-70.

Maulina, Lena, and Nining Sugihartini. 2015. "Formulasi Gel Ekstrak Etanol Kulit Buah Manggis (Garcinia Mangostana L.) dengan Variasi Gelling Agent sebagai Sediaan Luka Bakar." Pharmaciana 5(1):43-52.

Nanda, Y., Nur M. Salim, and Cut D. Iskandar. 2017. "Hispatologi Kulit Mencit (Mus Musculus) Fase Remodeling Pada Penyambuhan Luka Sayat Dengan Salep Getah Jarak Pagar (Jatropha Curcas Linn).” Jurnal Ilmiah Mahasiswa Veteriner 01(4):780-87.

Nugroho, Agung Endro. 2020. "Garcinia Mangostana Mangosteen.” Biotechnology of Fruit and Nut Crops 154-63.

Ovalle-Magallanes, Berenice, Dianelena Eugenio-Pérez, and José Pedraza-Chaverri. 2017.

"Medicinal Properties of Mangosteen (Garcinia Mangostana L.): A Comprehensive Update." Food and Chemical Toxicology 109:102-22.

Parmita, Risci Intan, Muhammad In, and Ita Armyanti. 2017. "Uji Efek Antiinflamasi Kombinasi Astaxanthin Dan Ekstrak Kulit Manggis ( Garcinia Mangostana Linn ) Pada Tikus Putih Galur Wistar Abstrak PENDAHULUAN Inflamasi Merupakan Suatu Respon Protektif Yang Ditujukan Drug / NSAID ) Namun Memiliki Efek Samping Yang." 3:689-96.

Puspitaningrum, Ika, Lia Kusmita, and Wahyuning Setyani. 2014. "Efek Analgetik Antipiretik Ekstrak Etanol Kulit Buah Manggis (Garcinia Mangostana L.) Pada Tikus Putih Jantan Galur Wistar.” E-Publikasi Ilmiah Fakultas Farmasi Unwahas Semarang 11(1):18-24.

Putra SR. 2012. Rahasia-Rahasia Keajaiban Kulit Buah Manggis. Cetakan 1. Jogjakarta: Diva Press.

Putri, Gemonia Ananda. 2020. "Pada Penyembuhan Luka Soket Pasca Pencabutan Gigi Tikus Putih Galur Wistar ( Rattus Novergicus ) Secara Hematoxilin Eosin ( He ) Universitas Sumatera Utara Medan 2020."

Putri, W. S., N. K. Warditiani, and L. P. F. Larasanty. 2013. "Skrining Fitokimia Ekstrak Etil Asetat Kulit Buah Manggis ( Garcinia Mangostana L .).” Journal Pharmacon 09(4):5659.

Riskesdas. 2013. Riskesdas.

Sorongan, Ryan Stefanus, and Krista V Siagian. 2015. "Efektivitas Perasan Daun Pepaya Terhadap Aktivitas Fibroblas Pasca Pencabutan Gigi Pada Tikus Wistar Jantan." Pharmacon 4(4):52-57.

Sugiaman, Vinna K. 2011. "Peningkatan Penyembuhan Luka Di Mukosa Oral Melalui Pemberian Aloe Vera ( Linn .) Secara Topikal Topical." Maranatha Journal of Medicine and Health 11(1):70-79.

Sumbayak, Erma Mexcorry. 2015. "Tinjauan Pustaka Fibroblas : Struktur Dan Peranannya Dalam Penyembuhan Luka.” Jurnal Kedokteran Meditek 21(6):1-6.

Suryadi, Iwan Antara. 2013. "Wound Healing Process and Wound Care." E-Jurnal Medika Udayana 2(2):254-72. 
Wehantouw, Frenly, and Sondang Manurung. 2011. "Aktivitas Antihiperglikemik Ekstrak Kulit Manggis (Garcinia Mangostana L.) pada Tikus yang Diinduksi Sukrosa." Chemistry Progress 4(2):89-96.

Yanti, Dharma. 2021. "Perbandingan Aktivitas Antioksidan Dan Toksisitas Antara Daging Buah, Kulit Bagian Dalam Dan Kulit Bagian Luar Buah Manggis (Garcinia Mangostana L.).” Jurnal Ayurveda Medistra 3(1):27-34.

Yulia, Avira Rizqiana. 2013. "Pengaruh Ekstrak Kulit Buah Manggis (Garcinia Mangostana L.) terhadap Jumlah Fibroblas pada Gingiva Tikus Wistar Jantan Pasca Induksi Porphyromonas Gingivalis." Fakultas Kedokteran Gigi Universitas Jember (Skripsi):14-27. 